\title{
Youtube Channel "Kokbisa" As Platform for Science and Environmental Communication
}

\author{
Detta Rahmawan ${ }^{1}$, Jimi N Mahameruaji ${ }^{2}$, Renata Anisa ${ }^{3}$ \\ Padjadjaran University, Bandung, Indonesia ${ }^{1,2,3}$ \\ \{detta@unpad.ac.id $\left.{ }^{1}\right\}$
}

\begin{abstract}
It has been suggested that on the Internet, and especially on social media like YouTube, negative contents are more popular than positive contents. YoutTube, for many young people in Indonesia, is used primarily for sources of entertainment instead of educational information. Drawn from our study on Indonesian YouTube business with a focus on one particular YouTube Channel "KokBisa" (youtube.com/kokbisa) and their community, we explore the opportunities and challenges for YouTube to be used as an educational platform for science and environmental communication. This article argues that there is a common agreement that positive content on YouTube (one of which talks about science and environmental issues) needs to be multiplied since there are very limited Indonesian YouTubers who focused on educational content. However, there are also challenges related to the development of such educational channel and community, particularly in terms of lack of exposure and also the sustainability factors, e.g. resources and channel monetization. YouTube-related research in Indonesia is currently emerging yet only a few focused on its potential as platforms for educational purpose, therefore it is hoped that this research can expand the discourse on YouTube in Indonesia
\end{abstract}

Keywords: Youtube, Channel, Educational

\section{Introduction}

Social media gave birth to various ways of diffusion of information. On the other hand, social media also spawned a variety of content with negative impacts. Such as how Facebook, Twitter, and Instagram affecting our level of stress and anxiety, mood, sleep patterns, selfesteem, etc. [1]. Social media today has deeply penetrated the lives of Indonesians. However, the rapid penetration of social media has not been offset by sufficient literacy rates [2] and digital literacy skills. Hence there are concern about negative implications of social media such as the proliferation of hoax and hate speech, cyberbullying, terrorism, radicalism, and social media addiction [3]. One crucial way to counter the effects of negative content is to increase the spread of positive content. While the term "positive content" might have multiple interpretations, we argue that one can be categorized as positive content if it contains sciencebased information and serves an educational purpose.

Furthermore, Indonesian Minister of Communication and Informatics, Rudiantara, in an interview said that in 2019 or 2020, positive content should "dominate" Indonesian digital sphere [4]. In Indonesia, the need for a platform for science and environmental communication 
on social media has not been fulfilled. It is necessary to learn more about how social media could be utilized not only for social connection, and entertainment, but also for educational purposes, to spread awareness about science and environmental issues, especially for young people who are living in big cities in Indonesia, and spent many of their hours connected to the Internet. Hence, this article aims to explore the notion of YouTube as a platform for science and environmental communication using the case study from Indonesian YouTube channel "KokBisa".

\section{Literature review}

\subsection{Social Media for Educational Purposes}

The utilization of social media for educational purposes required the audience to have the various skill necessary to properly understand and utilize the technology[5]. It can be said that the notion of understanding and utilizing technology mainly related to digital literacy. In 2014, a conference in Paris initiated by UNESCO addressed the urgency of the media literacy programs related to the rapid development of information and communications technologies around the world. In this meeting, it was concluded that digital literacy is necessary for the development of wider community [6]. Digital literacy, however, is not essentially similar to "computer literacy." Digital literacy does not only relate to basic computer and software skill in a functional perspective, such as how to use a word processor, copy and paste document, save data, manage files, etc. While digital literacy should move beyond functional perspective, the digitally literate individual in this context can be defined as "one who can search efficiently, who compares a range of sources, and sorts authoritative from non-authoritative, and relevant from irrelevant, documents[7]. This definition is useful in terms of how one uses and navigate various technologies, including social media to find information relevant to his needs.

According to the notion of participatory digital culture, social media have the potential to link formal and informal learning[8]. Research on the utilization of social media for learning suggested that the platforms can be utilized for collaboration and interaction, as well as sharing resources and information[9] and also engaging audience participation[10]. Other studies remind that there is a chance that social media is not preferable for tools of learning and more of course-related tools of communication[11] or only for non-academic socialization[12]. Therefore, it can be said that the use of social media for educational purposes has its challenges where one of the challenges can also be elaborated through the concept of science communication.

\subsection{Science Communication}

There is a broad notion of science communication in the academic literature. Social media can be used as a creative platform for communicating science and environmental issues [13]. In this article, the practice of science communication in YouTube specifically referred to "any video that might be seen as a form of science journalism that is not overtly didactic or instructional, while also not being principally focused on entertainment"[14]. Furthermore, the "actor" of science communication today is not only limited to those who work in formal, science-related sectors (e.g., academics, scientists) but also "interest groups, professional organizations, and passionate amateurs" [ibid]. 
Among various popular social media platforms in Indonesia today, it can be said that YouTube is particularly important for many young people as a platform for entertainment and information in the form of video. Content creators on YouTube or "YouTuber" are also influential in the lives of Indonesian youth and millennials[15]. The majority of content available in Indonesian YouTube sphere are of entertainment content. The potential for educational content on YouTube is one of the aspects that has not yet been optimized. Most content creators still follow the trend and often create mainstream contents. Therefore, in the future, it is possible that YouTube is also focusing on content creators and YouTuber's community that focuses on educational content[16]. These facts show that YouTube, in particular, is a potential platform for science communication, and disseminating environmental issues.

Today, with the abundance of information on the internet and social media, it is important to understand how to capture attention and how to spread messages that can be heard by the audience. Furthermore, a general understanding of the factors which contribute to the growth and popularity of a particular channel is necessary to explain the sustainability of utilizing YouTube as platforms for educational purpose.

METHOD

This article drew from studies on YouTube business in Indonesia and one particular youtube channel named KokBisa. Data were primarily collected from the qualitative content exploration of KokBisa's YouTube channel, and various source of media reporting related to KokBisachannel. Furthermore, we also interviewed with one representative from YouTube and five experts from digital media and advertising industry. Thematic analysis [17] was used to draw the results and conclusions.

\section{Results and discussion}

\subsection{Establishing Educational Community}

KokBisa (https://www.youtube.com/kokbisa) is a YouTube channel that focuses on delivering content that aims to answer random questions in everyday life based on scientific explanation. Content related to environmental issues ranging from global warming, environmental concerns in Indonesia, food waste, simple explanations on gravity, lunar eclipses, to the tsunami. KokBisa, which established in 2015, is an initiative founded by Gerald Sebastian, Alvin Disatputra, and Ketut Yoga Yudistira[18]. One of the founders, in an interview with daily social.id explained that; "Initially we made this channel because [we are] concerned that there are many shows with bad quality in Indonesia. Hence, we made the concept of presenting educational channels [by] using infographics" [ibid.]. For the topic of their video, usually, KokBisa's team start by looking for simple but popular questions that people are talking about.

Interestingly, KokBisa's team also often ask for input from their subscribers about potential themes or topics that can be made into their next video. After the theme has been decided, they will conduct simple research done through books, international journals, credible websites, and then written it into scripts, before they made illustrations and voice over for the video animation[19]. The amount of time needed to create a content is varying depend on the depth of the topics and the data they found.

When this article was written, KokBisa has produced 181 videos, made 81.530.446 views, and 838,930 subscribers. KokBisa has been monetized and earned money from YouTube. Thus it is no longer needed to be self-funded by Gerald, Alvin and Ketut like how it used to be 
when they first created the channel. In terms of the content, KokBisa mainly produces a short, simple animated video with bright colors and easily digestible explanations. KokBisa also provides the script and some of the primary sources they used for the content creation on their bloghttps://kokbisachannel.wordpress.com.

As the leaders in science-related educational content in Indonesian YouTube channels, KokBisa's style has been followed by other content creators. However, KokBisa's team said that the fact that more Indonesian channels making educational content are actually a good thing, and they do not mind that their styles are followed by other channels, as long as there is no one plagiarize their content. They are also very enthusiastic about networking with the fellow content creator that focuses on educational content. Not only producing content, from 2017, KokBisa's team also regularly hold several offline discussions with science-related themes called "Antero." Antero is an event created by KokBisa which bring together various science enthusiasts and communities in Indonesia. Until 2018, this discussion has been held six times, and all event has proven successful. Many speakers with different backgrounds such as lecturers, researchers, to comic artists have been invited to talk about various science and environmental-related themes e.g. "Will Technology Replace Humans?"; "Science from the Fiction World"; "Is There Another Life Outside the Earth?"; "The Dying Earth"; "Is It Possible that Humans Have Real Super Powers"; and "Do We Need to Go into Space?".

While KokBisa's numbers (as in subscribers and video views) is promising, it can be said that spreading educational content on YouTube alone is not enough and it is necessary to build a sense of communities, particularly with the offline discussion. KokBisa's science discussion gains great attention from the public which shows that the demand for educational and science-based discussion by actors outside formal educational institutions is fairly high. In fact, YouTube itself is actively encouraging the development of educational content, as shown in their page "starting an educational channel on YouTube" (https://creatoracademy.youtube.com/page/lesson/edu-channel-start), and also on a larger scale, YouTube also specifically promote content creators that have the potential to perform social change through "YouTube Creators for Change" initiative (https://www.youtube.com/yt/creators-for-change/).

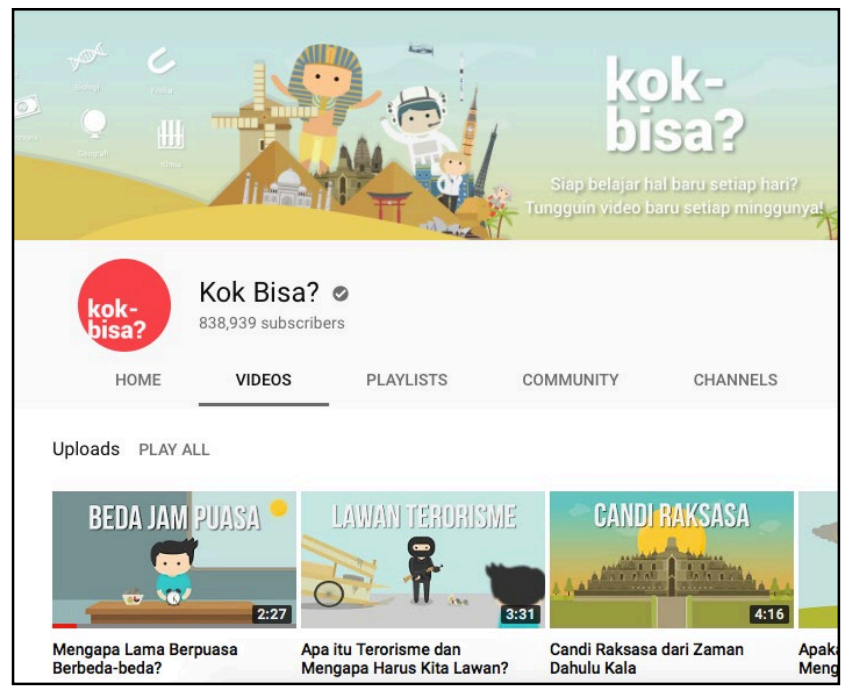

Figure 1.Screen Capture from KokBisa's YouTube channel. 
Source: Personal documentation

\subsection{Challenges Faced: Problems of Sustainability}

While Indonesia is seen as a country which has consistent internet penetration in years, there are interesting data related to a group of people who have created a Facebook account and use it regularly yet they said that they are not considered themselves as Internet users. Something similar happened in Africa, which raise a concern that for people in developing countries like in Indonesia and Africa, their internet access is dominated by activities on Facebook[20], [21]. The lack of basic knowledge about internet access by some of the people in Indonesia is one of the causes related to the underutilization of the internet as a potential source of information and educational content.

Survey on Indonesian digital media usage[22] illustrates how Indonesian are attached to social media, yet it has been suggested that $\mathrm{TV}$ is still the most powerful media in Indonesia[23]. Furthermore, the latest national survey of 1200 respondents spread across Indonesia shows that the majority of the respondents still choose television as the main media to obtain news and political information[24]. Another report also indicates that most of the Internet users in Indonesia who installed social media use it primarily for leisure or entertainment, and social connection[25].

From the data that we extracted through Social Blade website in 2018, we found that among 250 YouTube channel with the most subscribers in Indonesia, only fifteen accounts listed as education channel. However, a closer look at these fifteen accounts reveals that there are accounts which actually contain religion-based content, how-to videos, and even click-bait conspiracy or shallow videos. Among these accounts, only one account who actually produce science-based educational content that is KokBisa Channel [26]. Hence, Social Blade categorization system cannot be used as the only source to portrays the lack of YouTube channel with educational content in Indonesia. However, it does give statistical data that topsubscribed YouTube channel in Indonesia is mainly related to entertainment.

We argue that one of the crucial issues of educational content on YouTube is related to sustainability. Lack of YouTube channels with educational content in Indonesia also shows that these accounts are not getting enough exposure compared to entertainment channels. For example, if we do a simple search with Google search using the keyword "Konten Pendidikan di YouTube Indonesia" (educational content on YouTube Indonesia), there is no coverage from Indonesian mainstream media on the first page. Furthermore, some coverage is also not the latest updated news. Another problem for the education-based channel related to sustainability is about channel monetization. The issue of popularity is important since in YouTube ecosystem channel sustainability is strongly linked with its popularity. Consistently producing content requires various resources, especially if the channel run by personal content creator such as KokBisa, and not run by a formal educational institution. The popularity of a YouTube channel is at least related to three factors; content, creators, and YouTube's algorithm[14]. Low popularity of the channel with educational content would make the channel less attractive to advertisers, either as a brand endorser or by the Google AdSense system. This should be an important consideration toward the sustainability of Educational Content in YouTube. 


\section{Conclusion}

Indonesia has problems related to science and literacy rates and digital literacy skills. Hence, potential usage of internet is underutilized, and Internet penetration has not yet created a positive impact in the society. Entertainment contents on YouTube are far more popular than educational contents. As such, young people as the primary users of YouTube have not maximized this platform as a source of knowledge and educational information. This study selected "KokBisa" YouTube channel as a case study to analyze the opportunities and challenges for utilizing YouTube as a platform for science and environmental communication. The results show that opportunities for creating educational content are promising since there are limited content creators in this genre.

Furthermore, we argued that the demand and enthusiasm on educational content in social media, especially content designed for young people are also quite high. Content creators who focused in educational content also have to establish networks and engage with the broader educational community since "The biggest mistake that content creators can make is in viewing YouTube as merely a video hosting platform, rather than a participatory community"[14]. However, there are several challenges related to channel's sustainability, such as lack of exposure from mainstream media, and channel monetization. Research on YouTube in Indonesia is still increasing. Few studies shed light on YouTube for educational purpose. Therefore, it is hoped that this research can expand the discourse on YouTube in Indonesia.

\section{References}

[1] J. Brown, "Is Social Media bad for you? The evidence and the unknowns," BBC, 2018. [Online]. Available: http://www.bbc.com/future/story/20180104-is-social-media-badfor-you-the-evidence-and-the-unknowns.

[2] S. A. Gunawan, "Indonesia second least literate of 61 nations," The Jakarta Post, $2015 . \quad$ [Online]. Available: https://www.thejakartapost.com/news/2016/03/12/indonesia-second-least-literate-61nations.html.

[3] N. Kurnia and I. S. Astuti, "Researchers find Indonesia needs more digital literacy education," the conversation, 2017. [Online]. Available: $\mathrm{http}: / /$ theconversation.com/researchers-find-indonesia-needs-more-digital-literacyeducation-84570.

[4] K. F. Bohang, "Kominfo Targetkan 2019 Konten Positif Dominasi Internet Indonesia," Kementerian Komunikasi dan Informatika Republik Indonesia, 2017. [Online]. Available: https://www.kominfo.go.id/content/detail/10442/kominfo-targetkan-2019konten-positif-dominasi-internet-indonesia/0/sorotan_media.

[5] D. Buckingham, "Defining digital literacy - What do young people need to know about digital media?," Nord. J. Digit. Lit., pp. 21-34, 2015.

[6] UNESCO, "Paris Declaration on Media and Information Literacy in the Digital Age," UNESCO, 2014. [Online]. Available: http://www.unesco.org/new/fileadmin/MULTIMEDIA/HQ/CI/CI/pdf/news/paris_mil_ declaration.pdf.

[7] S. Livingstone, E. van Couvering, and N. Thumim, "Adult Media Literacy: A Review 
of the Research Literature," London, 2005.

[8] C. Greenhow and C. Lewin, "Social media and education: reconceptualizing the boundaries of formal and informal learning," Learn. Media Technol., vol. 41, no. 1, pp. 6-30, Jan. 2016.

[9] S. G. Mazman and Y. K. Usluel, "Modeling educational usage of Facebook," Comput. Educ., vol. 55, no. 2, pp. 444-453, Sep. 2010.

[10] R. Mason and F. Rennie, "Using Web 2.0 for learning in the community," Internet High. Educ., vol. 10, no. 3, pp. 196-203, Jan. 2007.

[11] J. Prescott, S. Wilson, and G. Becket, "Facebook use in the learning environment: do students want this?," Learn. Media Technol., vol. 38, no. 3, pp. 345-350, Sep. 2013.

[12] N. Selwyn, "Faceworking: exploring students' education-related use of Facebook," Learn. Media Technol., vol. 34, no. 2, pp. 157-174, Jun. 2009.

[13] A. G. Anderson, Media, Environment and the Network Society. New York: Palgrave Macmillan, 2014.

[14] D. J. Welbourne and W. J. Grant, "Science communication on YouTube: Factors that affect channel and video popularity," Public Underst. Sci., vol. 25, no. 6, pp. 706-718, Aug. 2016.

[15] D. Rahmawan, N. J. Mahameruaji, and H. Hafiar, "Peran Vlogger Sebagai Online Inflluencer dalam Industri Media Digital di Indonesia," Promedia, vol. 3, no. 2, pp. 183-206, 2017.

[16] N. J. Mahameruaji, L. Puspitasari, E. Rosfiantika, and D. Rahmawan, "Bisnis Vlogging dalam Industri Media Digital di Indonesia,” J. Іти Котип., vol. 15, no. 1, pp. 61-74, 2018.

[17] R. Boyatzis, Qualitative Information: Thematic Analysis and Code Development. California: Sage Publications, 1998.

[18] P. E. Setyanti, "Kok Bisa Hadirkan Channel YouTube Edukasi Alternatif Berbasis Video Infografis," Tech In Asia, 2015.

[19] kumparanNews, "Belajar Asyik via YouTube dengan 'Kok Bisa?," kumparan, 2017. [Online]. Available: https://kumparan.com/@kumparannews/belajar-asyik-viayoutube-dengan-kok-bisa.

[20] L. Mirani, "Different Worlds: Millions of Facebook users have no idea they're using the internet," Quartz, 2015. [Online]. Available: https://qz.com/333313/milliions-offacebook-users-have-no-idea-theyre-using-the-internet/.

[21] H. Pratiwi, "Many People, Including Indonesians, Still Consider Facebook as More Popular than Internet," Daily Social, 2015. .

[22] APJII, "Survei Penetrasi dan Perilaku Pengguna Internet Indonesia 2017," Jakarta, 2017.

[23] Nielsen, “Tren Baru di Kalangan Pengguna Internet di Indonesia," Jakarta, 2017.

[24] Lembaga Survei Kedai Kopi, "Survei Nasional Opini Publik 2018," Jakarta, 2018.

[25] comScore, "The Global Mobile Report 2017," 2017.

[26] Social Blade, "Top 250 YouTubers in Indonesia sorted by Subscribers," Social Blade, $2018 . \quad$ [Online]. Available: https://socialblade.com/youtube/top/country/id/mostsubscribed. 